Rocznik Gdański, t. LXXX 2020 PL ISSN 0080-3456

https://doi.org/10.26881/rgtn.2020.07

MATEUSZ RUTKOWSKI

Uniwersytet Gdański, Studia Doktoranckie Wydziału Nauk Społecznych w zakresie Pedagogiki https://orcid.org/0000-0003-4050-402X

\title{
WPŁYW PANDEMII COVID-19 NA POMORSKI RYNEK PRACY
}

\section{Wprowadzenie}

W niedawno opublikowanej książce Eduwidma. Miejsca i rzeczy nawiedzone, skupiającej się na aparaturze pojęciowej Jacques’a Derridy, w szczególności zaś na jego kryptach i widmach, pisałem o widmowaniu bezrobocia: „[...] brak pracy ponownie powróci, jego skala ulegnie ponownemu wzrostowi, jednak nie można przewidzieć, w jakiej postaci" ${ }^{1}$. Wniosek ten okazał się (chciałoby się powiedzieć: nieszczęśliwie) trafny.

We wspomnianym artykule analizowałem dane Głównego Urzędu Statystycznego dotyczące bezrobocia w latach 1990-2019 oraz wskazywałem na czasowe przybieranie na sile tego zjawiska. W kolejno następujących po sobie okresach bezrobocie w Polsce naprzemiennie rośnie i maleje - jak wskazuje Katarzyna Ślebarska², jego rozmiar ulega ciągłym zmianom, co jest ściśle uzależnione od aktualnych wydarzeń. Obecnie takim wydarzeniem jest wybuch pandemii COVID-19, co zmieniło dotychczasowy sposób życia ludzi na całym świecie, a zmiany te dotknęły wszystkich sfer funkcjonowania - także zawodowego. Pandemię za Nassimem Nicholasem Talebem możemy nazwać „czarnym łabędziem” - zjawiskiem, które wywołuje poważne skutki, jest nieprzewidywalne, a znalezienie przyczyn jego wystąpienia możliwe jest dopiero po pewnym czasie ${ }^{3}$. Wpływ pandemii na rynek pracy spełnia wymienione kryteria: pojawienie się kryzysu pandemicznego było nieprzewidywalne, wciąż wywołuje poważne i negatywne skutki, a jego wystąpienie, tak jak i konsekwencje, nie są możliwe do określenia w chwili bieżącej. Mimo iż skutki

1 M. Rutkowski, Krypty pracy/nie-pracy, widmowanie bezrobocia i inne uobecnienia społecznej zbędności. Perspektywa społeczno-edukacyjna [w:] Eduwidma. Miejsca i rzeczy nawiedzone, red. M. Mendel, Gdańsk 2020, s. 272.

2 K. Ślebarska, Wsparcie społeczne a zaradność człowieka w sytuacji bezrobocia. Studium konfrontatywne, Katowice 2010, s. 20.

3 Cyt. za: A.A. Zych, Aktywność zawodowa osób starszych na rynku pracy w cieniu pandemii koronawirusa, „Praca Socjalna” 2020, nr 6 (35), s. 23. 
pandemii są coraz bardziej dostrzegalne i dotkliwe, wskazanie i oszacowanie prawdziwej ich skali będzie możliwe dopiero w przyszłości - najprawdopodobniej długo po jej zakończeniu.

Problemem podejmowanym w artykule i zarazem jego celem jest ocena wpływu pandemii SARS-CoV-2 na sytuację na pomorskim rynku pracy w 2020 r. Analizy skupiają się wokół trzech kwestii. Pierwsza to opis ogólnej kondycji rynku pracy i zatrudnienia w województwie pomorskim. Pozostałe dotyczą charakterystyki sytuacji dwóch wybranych grup, które najsilniej doświadczają negatywnych skutków pandemii, tj. osób młodych oraz kobiet.

\section{COVID-19 a sytuacja na pomorskim rynku pracy}

Sytuacja na pomorskim rynku pracy do początku 2020 r. była jedną z najlepszych w kraju. Druga połowa 2019 r. przyniosła rekordowo niską stopę bezrobocia, która od czerwca do grudnia 2019 r. wynosiła 4,4\% . Biorąc pod uwagę dane Głównego Urzędu Statystycznego za 2019 r., pomorskie znalazło się na piątym miejscu w Polsce wśród województw o najniższej stopie bezrobocia rejestrowanego (które wynosiło wówczas 4,5\%). Wyżej znalazły się województwa: wielkopolskie (2,8\%), śląskie (3,6\%), małopolskie $(4,1 \%)$ i mazowieckie $(4,4 \%)^{5}$.

Wybuch pandemii COVID-19 spowodował, że stopa bezrobocia w województwie pomorskim w okresie kwiecień-listopad 2020 r. rosła. Według stanów na koniec miesiąca, stopa bezrobocia rejestrowanego wynosiła 6 : w marcu 4,8\%, kwietniu 5,2\%, od maja do lipca po 5,5\%, w sierpniu 5,6\%, wrześniu 5,7\%, październiku i listopadzie po 5,8\% $\%^{7}$ Z danych za marzec i listopad 2020 r. wynika, że stopa bezrobocia wzrosła w niemal wszystkich powiatach województwa pomorskiego, a wielkość wzrostu mieści się w przedziale 0,3-2,3 pkt. proc. Największą różnicę odnotowano w powiatach: słupskim (2,3 pkt. proc.), nowodworskim (1,9 pkt. proc.), m. Słupsku (1,8 pkt. proc.), człuchowskim (1,6 pkt. proc.) oraz malborskim (1,5 pkt. proc.). Wyjątek stanowi powiat bytowski, w którym w tożsamym okresie stopa bezrobocia spadła z 9,5\% do $9,4 \%$, jednak jest to tylko różnica pomiędzy krańcowymi miesiącami, bowiem $\mathrm{w}$ ciągu roku bezrobocie w tym powiecie również rosło ${ }^{8}$.

4 D. Maciejewska, B. Zabłocka, Miniony rok zakończyliśmy rekordowo niską stopa bezrobocia 4,4\%, www.porp.pl/pl/pomorskie-z-rekordowo-niska-stopa-bezrobocia-w-2019 [dostęp: 21.12.2020].

5 Dane Banku Danych Lokalnych, www.bdl.stat.gov.pl/BDL/start [dostęp: 21.12.2020].

6 W artykule wykorzystuję dane z opracowań Wydziału Pomorskiego Obserwatorium Rynku Pracy (dalej: PORP) i Wojewódzkiego Urzędu Pracy w Gdańsku (dalej: WUP Gdańsk). Nie wszystkie dane są udostępnione do powszechnej informacji, stąd też niektóre mogą różnić się zakresem szczegółowości.

7 Informacja miesięczna o rynku pracy - listopad 2020 r. Wydział Pomorskiego Obserwatorium Rynku Pracy, Wojewódzki Urząd Pracy w Gdańsku, www.porp.pl/uploads/original/012021/08/ aabe478bc8_Informacja-miesieczna-listopad-2020.pdf [dostęp: 9.12.2020].

8 Szacunkowe dane o rynku pracy w województwie pomorskim - listopad 2020 r. Wydział Pomorskiego Obserwatorium Rynku Pracy, Wojewódzki Urząd Pracy w Gdańsku, www.porp.pl/uploads/ original/122020/09/cf75b6618b_szacunkowe-dane-listopad-2020-r.pdf [dostęp: 9.12.2020]. 
Niezmiennie charakterystyczną cechą bezrobocia w województwie pomorskim jest jego przestrzenne zróżnicowanie. Niższa stopa bezrobocia występuje w powiatach zlokalizowanych w centrum województwa, a wyższa dotyczy jego wschodniej i zachodniej części ${ }^{9}$. Potwierdzają to wartości stopy bezrobocia w powiatach - według stanu na listopad 2020 r. najwyższa stopa bezrobocia dotyczy powiatów: nowodworskiego $(14,7 \%)$, malborskiego $(11,7 \%)$ oraz człuchowskiego $(11,2 \%)$, a najniższa - Trójmiasta: Sopot $(2,4 \%)$, Gdynia (3,3\%), Gdańsk (3,5\%), oraz powiatu kartuskiego $(4,0 \%)^{10}$.

Wzrost stopy bezrobocia jest spowodowany m.in. rosnącą przez cały rok liczbą osób bezrobotnych. Od lutego do listopada 2020 r. według stanów na koniec miesiąca liczba ta wzrosła o 10168 osób $^{11}$. Nie jest to jednak jedyna przyczyna, ponieważ jak czytamy w Ocenie sytuacji na rynku pracy województwa pomorskiego.... „Wzrost bezrobocia był spowodowany znacząco niższym odpływem osób bezrobotnych dotychczas figurujących w rejestrach, głównie z powodu wstrzymania realizacji aktywnych programów rynku pracy, zmniejszenia liczby wyłączeń z powodu niepotwierdzenia gotowości do podjęcia pracy, a także ograniczenia w świadczeniu usług pośrednictwa pracy. Liczba wyłączeń w kwietniu (czyli w najtrudniejszym okresie lockdownu) była o 6,7 tys., tj. o 74,4\% mniejsza niż w kwietniu 2019 r., a we wrześniu już tylko o 1,0 tys., tj. 12,7\% mniejsza niż w tym samym miesiącu roku ubiegłego"12.

Urzędy pracy, zarówno wojewódzkie, jak i powiatowe, w czasie pandemii zostały oddelegowane do wykonywania zadań związanych ze wsparciem w ramach tzw. tarczy antykryzysowej ${ }^{13}$. Szczególną rolę pełnią jednak urzędy powiatowe, które działają lokalnie i są odpowiedzialne za obsługę osób bezrobotnych, poszukujących pracy i pracodawcó $w^{14}$. Ze względu na obowiązujące obostrzenia powiatowe urzędy pracy nie realizowały działań aktywizacyjnych w takim zakresie, jak dotychczas, a ich działalność przede wszystkim skupiała się na realizacji nowych zadań nałożonych przez ustawodawcę ${ }^{15}$. To, w połączeniu ze złagodzeniem warunków pozostawania zarejestrowanym w urzędzie pracy (np. odstąpienia od wyrejestrowania bezrobotnego z powodu niepotwierdzenia gotowości do podjęcia pracy), spowodowało, że liczba wyłączeń $\mathrm{z}$ rejestrów uległa znacznemu zmniejszeniu.

9 Ocena sytuacji na rynku pracy województwa pomorskiego i realizacji przez Samorząd Województwa Pomorskiego zadań w zakresie polityki rynku pracy za rok 2020, oprac. Wydział Pomorskiego Obserwatorium Rynku Pracy, WUP Gdańsk, www.porp.pl/uploads/original/122020/01/2eb8a05818_ Ocena-sytuacji-na-pomorskim-rynku-pracy.pdf [dostęp: 1.12.2020], s. 12.

10 Szacunkowe dane o rynku pracy...

11 Tamże.

12 Ocena sytuacji na rynku pracy województwa pomorskiego..., s. 13.

13 L. Antkowiak, Publiczne stużby zatrudnienia w okresie pandemii COVID-19, www.porp. pl/uploads/original/122020/30/d3385e931b_LECH-ANTKOWIAK-ARTYKUL-NR-2.pdf [dostęp: 31.12.2020], s. 3-5.

14 E. Flaszyńska, Bezrobocie, bezrobotny, praca socjalna, Warszawa 2019, s. 52.

15 Więcej na ten temat zob. K. Falkowska, Nowa rola urzędów pracy w czasie pandemii - seminarium dobrych praktyk 2020, www.porp.pl/pl/nowa-rola-urzedow-pracy-w-czasie-pandemii [dostęp: 29.10.2020]. 
Analizując sytuację na rynku pracy w kontekście zatrudnienia, należy również odnieść się do kwestii dostępności miejsc pracy. W przypadku tego wskaźnika opisującego sytuację na rynku pracy w $2020 \mathrm{r}$. mamy do czynienia $\mathrm{z}$ wieloma fluktuacjami. Wpłynęła na to nie tylko pandemia, ale także rokrocznie obserwowane wahania sezonowe. Bez wątpienia jednak liczba wolnych miejsc pracy w 2020 r. jest mniejsza niż w roku ubiegłym: „Sumarycznie liczba zgłaszanych przez pomorskich pracodawców do powiatowych urzędów pracy wolnych miejsc pracy w okresie styczeńwrzesień $2020 \mathrm{r}$., w porównaniu z tym samym okresem roku ubiegłego, zmalała o 14 tysięcy. [...] Co warto zaznaczyć, zmieniająca się sytuacja nie zlikwidowała problemu pracodawców z pozyskiwaniem pracowników na wolne wakaty wynikających z tzw. luki kompetencyjnej widocznej w szczególności w branżach, takich jak: informatyka, transport i logistyka, opieka zdrowotna i nad osobami starszymi, budownictwo, gospodarka morska"16.

Jak podkreśla się w cytowanym fragmencie, liczba dostępnych w urzędach pracy ofert zatrudnienia w okresie początku pandemii i lockdownu spadła o prawie 50\%. Kolejne miesiące przyniosły odbicie, jednak ofert wciąż było mniej niż zazwyczaj, a mimo trudnej sytuacji pracodawcy borykali się z problemem z obsadzeniem wolnych miejsc pracy. Problemowi temu poświęcę później nieco więcej uwagi.

Dane w poniższej tabeli prezentują liczbę wolnych miejsc pracy i aktywizacji zawodowej zgłoszonych w powiatowych urzędach pracy województwa pomorskiego. Oferty te stanowią jedynie część dostępnych (pozostają jeszcze te, które nie zostały zgłoszone do instytucji), jednak tendencje w tym zakresie świadczą także o pewnych ogólnych zjawiskach na rynku pracy i w obszarze zatrudnienia.

Tabela 1. Wolne miejsca pracy i aktywizacji zawodowej w województwie pomorskim w $2020 \mathrm{r}$.

\begin{tabular}{|c|c|c|c|c|c|c|c|c|c|c|}
\hline $\begin{array}{l}\stackrel{\mathscr{W}}{\mathbb{U}} \\
\stackrel{\mathscr{E}}{\Sigma}\end{array}$ & 急 & $\begin{array}{l}\stackrel{U}{N} \\
\stackrel{\Xi}{\Sigma}\end{array}$ & 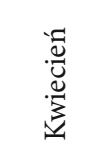 & $\sum^{\pi}$ & 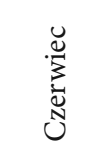 & 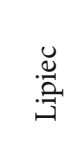 & 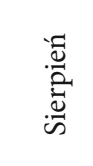 & $\begin{array}{l}\cdot \overline{0} \\
\stackrel{0}{0} \\
\text { N } \\
3\end{array}$ & 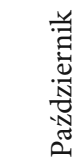 & 㺃 \\
\hline $\begin{array}{l}\text { liczba } \\
\text { wolnych } \\
\text { miejsc pracy }\end{array}$ & 8075 & 6689 & 4178 & 4517 & 6833 & 7369 & 6592 & 8599 & 6575 & 5051 \\
\hline
\end{tabular}

Źródło: opracowanie własne na podstawie: Szacunkowe dane o rynku pracy w województwie pomorskim - listopad 2020 r., Wydział Pomorskiego Obserwatorium Rynku Pracy, Wojewódzki Urząd Pracy w Gdańsku.

Wyróżnione w tabeli dane pokazują spadek liczby wolnych miejsc pracy w kwietniu i maju - a więc okresie, kiedy w Polsce mieliśmy do czynienia z pierwszą falą zachorowań

16 Ocena sytuacji na rynku pracy województwa pomorskiego..., s. 7. 
na COVID-19 oraz wprowadzeniem lockdownu. Jedynym miesiącem, który mógł świadczyć o powrocie do normalności, był wrzesień, kiedy liczba dostępnych ofert wyniosła 8599. Dane za ostatnie miesiące pokazują, że w najbliższym czasie ponownie będziemy mieli do czynienia ze znacznie mniejszą niż zazwyczaj liczbą wolnych miejsc pracy.

Jak wspomniałem, mimo niekorzystnej w wielu aspektach sytuacji na rynku pracy przedsiębiorcy niezmiennie borykają się z trudnościami w obsadzeniu wolnych miejsc pracy. Wśród czynników je powodujących, związanych z pandemią, znajdą się zarówno te po stronie pracodawców, jak i pracobiorców. W grupie przedsiębiorców można wskazać dwie kluczowe kwestie: ograniczenie, a nawet wstrzymanie rekrutacji (pomimo zapotrzebowania na pracowników, ze względu na niepewną sytuację w kraju i na świecie) oraz poszukiwanie określonych kandydatów - przede wszystkim doświadczonych i sprawdzonych pracowników. Pandemia spowodowała także zmianę podejścia osób poszukujących pracę - robią to mniej aktywnie i dynamicznie, a istotną sprawą są dla nich warunki zatrudnienia, w tym kwestia przestrzegania zasad BHP, warunki sanitarne oraz stabilność zatrudnienia. Poszukujący pracy przywiązują większą wagę do bezpieczeństwa w miejscu pracy, o czym świadczy fakt, że przyszli pracownicy mniej chętnie wybierają firmy, w których wystąpiły zakażenia wirusem SARS-CoV-2 ${ }^{17}$. Niezależnie jednak od sytuacji epidemiologicznej w województwie wciąż występuje luka kompetencyjna.

Pandemia powoduje, że sytuacja przedsiębiorców i pracowników ulega nieustannym przemianom. Jedni na niej tracą, inni zyskują - zarówno jeśli chodzi o pracodawców, jak i pracobiorców. Wspólnym mianownikiem dla nich jest poszukiwanie rozwiązań sytuacji, w której się znajdują, by zwiększać szansę na przetrwanie trudnego okresu i powrót do normalności.

Ważnym zjawiskiem na pomorskim rynku pracy jest wysoka popularność zatrudniania cudzoziemców. Na początku pandemii mieliśmy do czynienia ze spadkiem liczby oświadczeń o powierzeniu pracy cudzoziemcom, jednak regres miał charaktery wyłącznie chwilowy. W kwietniu 2020 r. pracę powierzono 3488 cudzoziemcom, a we wrześniu 2020 r. mieliśmy do czynienia z rekordowym wynikiem - 14160 zarejestrowanych oświadczeń ${ }^{18}$.

Kwietniowy spadek zatrudnienia cudzoziemców był wynikiem masowego opuszczania kraju z powodu pandemii ${ }^{19}$. Powodem wyjazdu cudzoziemców była niepewna sytuacja w kraju - ogólne obostrzenia (w tym przemieszczania się) oraz te związane z pracą i prowadzeniem działalności gospodarczej. Kolejne miesiące, po kwietniowym spadku, przynosiły wzrosty liczby zatrudnionych cudzoziemców i to mimo

17 M. Rutkowski, Pomorski rynek pracy w październiku - sytuacja się pogarsza i wzrasta niepewność przedsiębiorców, www.porp.pl/pl/pomorski-rynek-pracy-w-pazdzierniku-sytuacja-sie-pogarsza-i-wzrasta-niepewnosc-przedsiebiorcow [dostęp: 6.11.2020].

18 Informacja miesięczna o rynku pracy październik 2020 r., Wydział Pomorskiego Obserwatorium Rynku Pracy, Wojewódzki Urząd Pracy w Gdańsku, www.porp.pl/uploads/original/122020/09/ fd035d6e18_Informacja-miesieczna-pazdziernik-2020.pdf [dostęp: 9.12.2020].

19 Ocena sytuacji na rynku pracy województwa pomorskiego..., s. 18. 
negatywnych zjawisk na rynku pracy. Wzrost zainteresowania zatrudnianiem obcokrajowców przez pomorskich przedsiębiorców (który nadal się utrzymuje) wynika z dwóch czynników. Po pierwsze, mają oni wyższą motywację, co przekłada się na ich większą mobilność niż rodzimych pracowników ${ }^{20}$. Po drugie, w dobie pandemii są bardziej atrakcyjnymi pracownikami ze względu na dominującą w tej grupie formę zatrudnienia na umowy cywilnoprawne, co pozwala na zakończenie współpracy w dowolnym momencie, np. w sytuacji wprowadzenia kolejnych obostrzeń lub lockdownu.

Dzięki możliwości zatrudnienia osób pochodzących głównie zza wschodniej granicy pomorscy przedsiębiorcy mają szansę na uzupełnienie braków kadrowych, a przez to na poprawę stabilności prowadzonej działalności. Rodzimi pracownicy w perspektywie krótkookresowej mogą postrzegać to jako zjawisko negatywne, jednak dalekosiężne rezultaty takiego działania będą miały pozytywny wpływ na przyszłą sytuację lokalnego rynku - chociażby poprzez utrzymanie działalności firm oraz redukcję upadłości.

Dokonany krótki opis sytuacji na pomorskim rynku pracy w 2020 r. pozwala wysunąć wniosek, że wpływ pandemii COVID-19 jest negatywny. Rynek pracy pozostaje wrażliwy na wszelkiego rodzaju zmiany - różne wydarzenia, wprowadzanie ograniczeń w działalności podmiotów gospodarczych czy nowe rozwiązania prawne. Każde z nich może oddziaływać pozytywnie i negatywnie, dlatego podstawą podejmowania skutecznych interwencji jest ciągła i uważna obserwacja wydarzeń. Szczególnego zainteresowania - moim zdaniem - wymaga sytuacja dwóch grup osób na rynku pracy: kobiet i młodych. Jak czytamy w Informacji miesięcznej o rynku pracy październik $2020 \mathrm{r}$.: „, [...] blisko 60\% (32 520 osób) ogółu bezrobotnych stanowiły kobiety, a niemal 30\% (15 951) osoby młode w wieku do 30 lat" ${ }^{21}$.

\section{Młodzi, czyli ci, którzy przez pandemię tracą na rynku pracy najwięcej}

Szczególną grupą na rynku pracy są osoby młode ${ }^{22}$. Problemy tej grupy to niska aktywność zawodowa, wysoki poziom bezrobocia i bierności. Warto w tym kontekście przywołać słowa Kamili Kaczmarczyk: „Potwierdzeniem tego stanu jest wysokość stopy bezrobocia młodzieży w Polsce, która prawie dwukrotnie przewyższa stopę bezrobocia wyznaczoną dla ogółu osób w wieku produkcyjnym. Zjawiskiem równie niepokojącym jest skala bierności społecznej młodzieży - w 2014 r. niemal co siódma osoba młoda należała do populacji NEET [, not in employment, education or training" - przyp. M.R.]”23.

20 M. Rutkowski, Pomorski rynek pracy w październiku...

${ }_{21}$ Informacja miesięczna o rynku pracy październik 2020 r...

22 G. Spytek-Bandurska, Aktywizacja zawodowa szczególnych kategorii bezrobotnych, Warszawa 2010, s. 20.

23 K. Kaczmarczyk, Bierność i bezrobocie młodzieży w Polsce, Toruń 2016, s. 10. 
Młodzi mają więc nie tylko problem $\mathrm{z}$ odnalezieniem się na rynku pracy, ale również z określeniem swojej przyszłej ścieżki życiowej i zawodowej - o czym świadczy wysoki odsetek w tej grupie osób NEET. Jak podaje GUS, w III kwartale 2020 r. większość osób biernych zawodowo stanowili emeryci (57,6\%) oraz uczniowie i studenci $(16,5 \%)^{24}$. Jeśli zaś chodzi o bezrobotnych, to: „analizując strukturę osób bezrobotnych można zauważyć, że zmiany w tym zakresie w ciągu ostatniego roku nie były znaczące - o 0,2 pkt. proc zwiększył się odsetek osób młodych - do 25 r.ż. oraz o 0,5 pkt. proc. osób nieposiadających kwalifikacji zawodowych"25. W rzeczywistości statystyki nie oddają problemów, z jakimi w obliczu pandemii mierzą się młodzi pracujący oraz dopiero wchodzący na rynek pracy.

Pandemia i wprowadzane w związku z nią obostrzenia powodują, że młodzi najbardziej, bo z wielu stron, tracą na rynku pracy. Wśród przejawów owej straty można wymienić: spadek znaczenia młodych pracowników na poczet doświadczonych, utratę pracy ze względu na formę zatrudnienia i ograniczenie prowadzenia działalności gospodarczej w branżach, w których dominuje zatrudnienie osób młodych, oraz przy pracach sezonowych. Pokrótce omówię wymienione problemy młodych na rynku pracy.

Pandemia COVID-19 spowodowała, że z jednej strony mamy do czynienia ze spadkiem zatrudnienia osób młodych, a z drugiej - ze wzrostem znaczenia doświadczonych pracowników, którzy posiadają sprawdzone przez pracodawców kompetencje i kwalifikacje. Sprawdzeni pracownicy częściej utrzymują dotychczasowe zatrudnienie, ponieważ ich zwolnienie jest dla pracodawcy bardziej kosztowne, a jeśli je tracą - mają poważne problemy z ponownym znalezieniem ${ }^{26}$. Przedsiębiorcy niechętnie zatrudniają młodych ze względu na konieczność ich przyuczenia, na co w obecnej sytuacji epidemiologicznej w kraju i na świecie nie mogą sobie pozwolić - wymaga to czasu i generuje koszty.

Wspomniane już koszty rozwiązania współpracy z doświadczonymi pracownikami mają również znaczenie dla sytuacji młodych. Ze względu na dominującą w grupie młodych pracowników formę współpracy w oparciu o umowy cywilnoprawne są oni najbardziej narażeni na utratę pracy w czasie pandemii. Rozwiązanie takiej współpracy nie generuje żadnych kosztów, a ze względu na elastyczność zatrudnienia jest szeroko wykorzystywana przez przedsiębiorców - może ona zostać zawarta i zerwana w każdej chwili, np. w sytuacji wprowadzenia kolejnych obostrzeń.

24 Aktywność ekonomiczna ludności w województwie pomorskim w III kwartale 2020 r., Główny Urząd Statystyczny w Gdańsku, 2020, www.gdansk.stat.gov.pl/opracowania-biezace/opracowania-sygnalne/praca-wynagrodzenie/aktywnosc-ekonomiczna-ludnosci-w-wojewodztwie-pomorskim-w-iii-kwartale-2020-r-,3,43.html [dostęp: 7.12.2020], s. 6.

25 Ocena sytuacji na rynku pracy województwa pomorskiego..., s. 13.

26 M. Rutkowski, Pomorski rynek pracy w listopadzie - kolejne restrykcje i ich negatywne skutki, www.porp.pl/pl/pomorski-rynek-pracy-w-listopadzie-kolejne-restrykcje-i-ich-negatywne-skutki [dostęp: 9.12.2020]. 
Największym problemem jest jednak ograniczenie działalności gospodarczej w branżach, w których dominuje zatrudnienie osób młodych. W wyniku pandemii młodzi pracownicy wielokrotnie tracili pracę i okazję do jej podjęcia, m.in. w okresie lockdownu, sezonu wakacyjno-urlopowego czy po jego zakończeniu - kiedy we wrześniu i październiku studenci standardowo podejmowali pracę na okres roku akademickiego: „W tym roku studenci, w znacznie ograniczonym zakresie w stosunku do lat poprzednich, mogą liczyć na pracę $\mathrm{w}$ branży turystycznej oraz w usługach opiekuńczych, które dotychczas cieszyły się dużą popularnością w tej grupie pracujących. W szczególności dotyczy to miejsc pracy w restauracjach, pubach, barach, recepcjach hotelowych, salach zabaw dla dzieci czy w charakterze opieki dla dziecka. [...] szansą dla młodych jest praca w usługach, które w obecnej sytuacji epidemicznej zyskują na popularności, m.in. w sprzedaży, telekomunikacji, IT czy jako kurierzy rowerowi i skuterowi”27.

Młodzi tracą możliwość zarobkowania także w okresie świąt, który zwykle charakteryzuje się „wysypem” ofert prac dorywczych.

Obok opisanych już problemów młodzi wciąż borykają się z tymi znanymi od lat, tzn. $z$ brakiem standardowych miejsc pracy, gorszymi warunkami i formami zatrudnienia oraz relatywnie niższymi płacami, co przekłada się na ich niską aktywność zawodową. Zarówno stare, jak i nowe (wynikające z pandemii) trudności młodych na rynku pracy będą miały długofalowe i negatywne skutki, młodzi będą ich doświadczać jeszcze długo po zakończeniu kryzysu ${ }^{28}$. Druga grupa, której sytuację na rynku pracy w czasie pandemii omówię szerzej, to kobiety.

\section{Kobiety na rynku pracy w czasie COVID-19 - wykluczanie czy samowykluczanie?}

Magdalena Środa, powołująca się na kulturę patriarchatu oraz na dorobek Simone de Beauvoir, pokazuje, jak silnie zakorzenione w społeczeństwie traktowanie kobiet jako innych od mężczyzn powoduje, że są one poddawane opresji i wykluczeniu. Kobieta jest jedynie pewną konstrukcją, stanowiącą reprezentację męskich oczekiwań względem niej ${ }^{29}$. Sprzeczność owych wymagań adresowanych przez mężczyzn (a w konsekwencji także społeczeństwo w ogóle) względem kobiet trafnie prezentował film Be a Lady They Said, który w lutym 2020 r. obiegł cały świat ${ }^{30}$. We wspomnianym filmie aktorka i aktywistka Cynthia Nixon recytuje słowa Camille Rainville ${ }^{31}$ :

27 Tenże, Pomorski rynek pracy w październiku...

28 Tamże.

29 M. Środa, Obcy, inny, wykluczony, Gdańsk 2020, s. 109-111.

30 J. Właszczuk, Manifest feministyczny, który stał się wiralem, www.vogue.pl/a/manifest-feministyczny-ktory-stal-sie-wiralem [dostęp: 26.02.2020].

31 Cytat pochodzi z filmu z udziałem Cythii Nixon, dostępnego w serwisie YouTube pod nazwą Be a Lady They Said - Girls. Girls. Girls. Magazine. Pełna wersja manifestu Camille Rainville jest 
Be a lady they said. Don't talk too loud. Don't talk too much. Don't be intimidating. Why are you so miserable? Don't be a bitch. Don't be so bossy. Don't be so emotional. Don't cry. Don't yell. Don't swear. Endure the pain. Don't complain. Fold his clothes. Cook his dinner. Keep him happy. That's a woman's job. You'll make a good wife some day. Take his last name. You hyphenated your name? Crazy feminist. Give him children. You don't want children? You will someday. You'll change your mind ${ }^{32}$.

Kobieta - mimo licznych starań (w postaci działań edukacyjnych, akcji społecznych czy wprowadzania rozwiązań legislacyjnych zrównujących pozycję kobiet i mężczyzn np. na rynku pracy) - wciąż, niestety, stawiana jest w opozycji do mężczyzny, co podkreśla jej odmienność od przedstawicieli płci społecznie dominującej i jednocześnie wartościuje ją jako tę „gorszą”. Jak pisze M. Środa: „mężczyznę charakteryzuje aktywność, samodzielność, skuteczność, przemoc, dzielność, stałość, energia, racjonalizm, rozsądek, myślenie, umiejętność oceniania i abstrahowania, kobietę zaś - pasywność, zależność, łagodność, skromność, chwiejność, słabość, uczuciowość, wrażliwość, receptywność, wstydliwość, intuicyjność"33.

Oddziaływanie pandemii na rynek pracy spowodowało przynajmniej dwa silnie zaznaczające się zjawiska w kontekście aktywności zawodowej kobiet: przechodzenie kobiet w bierność zawodową oraz dezaktywizację zawodową i odraczanie powrotu na rynek pracy, spowodowane koniecznością sprawowania opieki nad osobami zależnymi (starszymi i dziećmi). Zjawiska te z jednej strony w pewnym stopniu potwierdzają opisywaną wcześniej dominację kultury patriarchalnej, z drugiej jednak pokazują, że rola kobiet jest nie do przecenienia dla dobrego funkcjonowania społeczeństwa. Jeśli kobiety stanęły przed koniecznością pozostania w domu ze względu na sprawowanie opieki nad osobami zależnymi, to było to warunkiem również tego, by mężczyźni mogli pozostać aktywni zawodowo. Warto podkreślić, że sprawowanie opieki jest w naszej kulturze wpisane w role kobiece, wiąże się bowiem z wymienianymi przez M. Środę cechami, m.in. wrażliwością czy uczuciowością - w tym przypadku uznawanymi za cechy pozytywne (czy nawet pożądane), a nie negatywne.

$\mathrm{Z}$ innej strony, potrzebę pozostania kobiet w domu można postrzegać jako przejaw dyskryminacji obok wciąż obecnych na rynku pracy nierówności płacowych, stanowiskowych czy gorszym dostępem do powrotu na rynek pracy ${ }^{34}$, co jest przykładem wykluczania ich z rynku pracy. Paweł Ulman nakreśla pewne pole samowykluczania kobiet z rynku pracy, spowodowane mniejszą niż u mężczyzn skłonnością do podejmowania ryzyka: „Jeśli bowiem mężczyźni są bardziej «ryzykowni» na rynku

dostępna na stronie: www.writingsofafuriouswoman.wordpress.com/2017/12/09/be-a-lady-they-said/ [dostęp: 25.01.2021].

32 BeaLady They Said-Girls. Girls. Girls. Magazine, www.youtube.com/watch?v=z8ZSDS7zVdU\&feature=emb_title [dostęp: 24.02.2020].

33 M. Środa, Obcy, inny, wykluczony..., s. 113.

34 P. Ulman, Sytuacja kobiet i mężczyzn na rynku pracy w Polsce [w:] Marginalizacja na rynku pracy. Teorie a implikacje praktyczne, red. N.G. Pikuła, Kraków 2015, s. 120-127. 
pracy, a kobiety bardziej preferują pewność pracy, to czy mężczyźni nie zyskują premii za ryzyko (oczywiście średnio rzecz ujmując)? Innymi słowy, czy kobiety nie «kupują» pewności pracy i lepszych jej warunków, "płacąc» niższą pensją?" 35 .

Moim zdaniem sprawa nie jest tak prosta, jak przedstawia cytowany autor. Nawet jeśli możemy mówić o mniejszej skłonności kobiet do podejmowania ryzyka na rynku pracy, to nie jest to sprawa linearna, wynikająca wyłącznie z podejścia kobiet. Jest ona odbiciem sytuacji społecznej, która powoduje, że kobiety czują się niepewnie na rynku pracy, są bardziej zagrożone negatywnymi zjawiskami niż mężczyźni. Jak pisze Elżbieta Sałata: „kobiety mają większe problemy ze znalezieniem pracy niż mężczyźni. Pracodawcy niechętnie je zatrudniają, tłumacząc to m.in. mniejszą dyspozycyjnością czy wychowywaniem dzieci" ${ }^{36}$. Stanowiska w sprawie niskiej aktywności zawodowej kobiet są podzielone, co zdaje się potwierdzać sprzeczność wymagań stawianych kobietom, o których pisała Camille Rainville.

Pandemia COVID-19 spowodowała, że obecność kobiet w domu w celu sprawowania opieki nad osobami zależnymi stała się ponownie istotna. Z perspektywy sytuacji tej grupy osób na rynku pracy niestety przekłada się to na negatywne tendencje. W Ocenie sytuacji na rynku pracy województwa pomorskiego... czytamy: „[...] porównując II kwartał 2019 i 2020 r. liczba pracujących zmniejszyła się o 17 tys., tj. o 1,7\%. Jest to efektem przede wszystkim spadku liczby pracujących kobiet o 21 tys. Tym samym udział kobiet w pracujących ogółem zmniejszył się o 1,4 pkt. proc., tj. z 44,4\% w II kwartale 2019 r. do 43,0\% w tym samym okresie roku 2020"37.

Pogorszenie sytuacji kobiet na rynku pracy bez wątpienia wiązało się z zamknięciem gospodarki w II kwartale 2020 r. Jak pokazują dane, w III kwartale tego roku tendencja ta odwróciła się, „[...] zmniejszyła się liczba biernych zawodowo kobiet, a jednocześnie wzrosła liczba kobiet pracujących i bezrobotnych" ${ }^{38}$.

W III kwartale 2020 r. w województwie pomorskim zaktywizowało się zawodowo więcej kobiet niż mężczyzn - liczba biernych mężczyzn zmniejszyła się o 137 tys. (2,7\%), a kobiet o 293 tys. (2,7\%). W pewnym stopniu osoby te przeszly do bezrobocia - w III kwartale 2020 r. (w stosunku do II kwartału) liczba bezrobotnych mężczyzn wzrosła o 12 tys., a kobiet o 62 tys. ${ }^{39}$ Jeśli zaś chodzi o przyczynę bierności zawodowej osób w wieku produkcyjnym, to najczęściej wskazywano obowiązki rodzinne $(33,5 \%)^{40}$. Od początku pandemii liczba kobiet zarejestrowanych w powiatowych urzędach pracy województwa pomorskiego rośnie z miesiąca na miesiąc.

35 Tamże, s. 128.

36 E. Sałata, Rola pracy zawodowej w życiu kobiet [w:] Marginalizacja na rynku pracy..., s. 131.

37 Ocena sytuacji na rynku pracy województwa pomorskiego..., s. 9.

38 M. Rutkowski, Pomorski rynek pracy $w$ listopadzie...

39 Aktywność ekonomiczna ludności w województwie pomorskim w III kwartale 2020 r., Główny Urząd Statystyczny w Gdańsku, 2020, www.gdansk.stat.gov.pl/opracowania-biezace/opracowania-sygnalne/praca-wynagrodzenie/aktywnosc-ekonomiczna-ludnosci-w-wojewodztwie-pomorskim-w-iii-kwartale-2020-r,3,43.html [dostęp: 7.12.2020].

40 Tamże, s. 6 
Wobec tak kształtującej się sytuacji kobiet na rynku pracy należy wskazać, że doświadczają one bardziej wykluczenia, niż wykluczają się same. Świadczy o tym nie tylko podejście pracodawców, którzy na zatrudnienie kobiet patrzą przez pryzmat ograniczeń, a nie możliwych korzyści płynących z ich pracy, ale także powrót do społecznego postrzegania ich jako „strażniczek domowego ogniska”. Nawet jeśli podejmują decyzję o pozostawaniu w domu (co błędnie można rozumieć jako przejaw samowykluczenia), to w przypadku pandemii jest to decyzja o wyborze „mniejszego zła" - spośród własnej aktywności zawodowej i trudniejszej sytuacji materialnej rodziny lub własnej bierności i pracy zarabiającego relatywnie więcej mężczyzny. Wybór w tym przypadku wydaje się być oczywisty.

Tak jak osoby młode, tak i kobiety będą borykały się z trudnościami na rynku pracy jeszcze długo po ustaniu pandemii. Niska aktywność zawodowa, wysokie bezrobocie i bierność wciąż charakteryzują sytuację kobiet na rynku pracy. W pewnym sensie pandemia ponownie wskazała miejsce kobiet w życiu społecznym - jest nim dom, w którym zajmują się sprawami codziennymi oraz opieką nad osobami zależnymi. Poszukując pozytywnych aspektów tej sytuacji, można powiedzieć, że kobiety okazały się istotnym ogniwem życia rodzinnego, a ich pozostanie w domach pozwoliło wielu mężczyznom utrzymać dotychczasowe zatrudnienie. Trudno jednak o równie pozytywne wnioski w kontekście ich pozycji na rynku pracy, która wciąż nie jest dobra, a o której poprawę walczą politycy, edukatorzy, aktywiści społeczni czy pracownicy publicznych służb zatrudnienia.

\section{Bezrobocie i społeczna marginalizacja - kontekst pandemiczny}

Andrzej Radziewicz-Winnicki pisze, że marginalizacja oznacza „nieuczestniczenie jednostek bądź grup społecznych w podstawowych instytucjach określonego porządku społecznego" ${ }^{\text {"1 }}$. Jako zjawisko niekorzystne marginalizacja powoduje różnicowanie społeczeństwa ${ }^{42}$, najogólniej mówiąc, na uczestniczących w głównym nurcie życia społecznego i tych, którym tego udziału się odmawia. Jedną z przyczyn marginalizacji jest właśnie status na rynku pracy, ponieważ: „status pracującego czy bezrobotnego na rynku pracy istotnie różnicuje osiąganą jakość życia [...] [w ten sposób, że - M.R.] osoby bezrobotne charakteryzują się istotnie gorszym poczuciem jakości życia, szczególnie w wymiarze rodzinnego, społecznego i zawodowego funkcjonowania, a także $\mathrm{w}$ aspekcie samooceny zdrowia i radzenia sobie" ${ }^{\prime 3}$.

$41 \quad$ A. Radziewicz-Winnicki, Pedagogika społeczna w obliczu realiów codzienności, Warszawa 2008, s. 248.

${ }^{42}$ K. Palka, Edukacja na wsi - mechanizmy wykluczenia edukacyjnego [w:] Pedagogika społeczna wobec zagrożeń człowieka i idei sprawiedliwości społecznej, V Zjazd Pedagogów Społecznych, t. 2, red. W. Danilewicz, W. Theiss, Warszawa 2014, s. 361.

${ }^{43}$ J. Kirenko, M. Duda, Bezrobocie - jakość życia - uwarunkowania, Lublin 2018, s. 389. 
Pracę uznaje się za jeden $\mathrm{z}$ warunków przeciwdziałających wykluczeniu społecznemu, gdyż uzyskiwane z niej dochody poprawiają jakość życia ${ }^{44}$. Na opisywany problem wpływu pandemii na rynek pracy warto spojrzeć przez pryzmat wykluczenia społecznego. W kontekście zatrudnienia ryzyko ekskluzji przybiera na sile. Jest to szczególnie dostrzegalne wśród osób z grup ryzyka (choćby tych opisanych w artykule - młodych i kobiet), w przypadku których mamy do czynienia z wykluczaniem wykluczonych. Pandemia powoduje, że zagrożeni jeszcze bardziej doświadczają negatywnych zjawisk.

Możliwość wykluczenia nie dotyczy obecnie wyłącznie grup ryzyka, ale poprzez nieprzewidywalność wydarzeń perspektywa ta zdaje się rozciągać na całe społeczeństwo. Decydującą rolę odgrywać będzie czas trwania pandemii oraz podejmowane działania prawno-polityczne, mające na celu ograniczanie negatywnych konsekwencji, a które w obecnym kształcie tylko w niewielkim stopniu odpowiadają na potrzeby przedsiębiorców.

Pandemia COVID-19 nie tylko powoduje nowe nierówności i wykluczenie, ale pogłębia już istniejące. Zmniejszająca się liczba dostępnych miejsc pracy jest problematyczna nie tylko dla osób, które tracą ją w wyniku pandemii, ale także dla osób długotrwale bezrobotnych, które np. podjęły się podnoszenia kwalifikacji, a mimo to będą miały poważne problemy ze znalezieniem pracy. „Nowi” bezrobotni, a więc ci, którzy stracili pracę $\mathrm{w}$ wyniku pandemii, $\mathrm{z}$ rejestracją $\mathrm{w}$ urzędzie pracy wiążą nadzieję na szybkie jej odnalezienie. Wsparcie w tym zakresie jest jednak ograniczone, urzędy realizują inne zadania nałożone szczególnymi przepisami, co oznacza zawieszenie działań aktywizacyjnych.

Opisana w artykule sytuacja młodych i kobiet na rynku pracy wskazuje na pogłębianie się dotychczasowych problemów, co wiąże się z rosnącym wykluczeniem. Zarówno przed pandemią, jak i obecnie „[...] nadal występuje dyskryminacja na rynku pracy ze względu na płeć i sprawność pracowników, a zdobyte kwalifikacje oraz kursy czy szkolenia obecnie nie stanowią decydującego atutu przy zatrudnianiu pracownika" ${ }^{45}$. Młodzi stają się coraz mniej atrakcyjną grupą na rynku ze względu na brak doświadczenia, a ich marginalizacja w wyniku pandemii ze względu na dominującą w tej grupie formę zatrudnienia czasowego przyjęła niemal ekspresową formę. Ich atutem pozostaje wiek, który przegrywa z doświadczeniem starszych pracowników. W konsekwencji młodzi pracownicy zostali pozbawieni nie tylko aktualnej pracy, ale także szansy na znalezienie nowej, szczególnie zaś w branży dotychczasowego zatrudnienia.

Pandemia prawdopodobnie pogłębi negatywne postrzeganie przedstawicieli opisanych grup na rynku pracy, co będzie oznaczało długi okres ich marginalizowania i powracania do aktywności zawodowej. Sytuacja epidemiczna w regionie i kraju

${ }_{44}$ B. Baraniak, Edukacja przygotowująca do pracy zawodowej szansa człowieka na wychodzenie z marginalizacji społecznej [w:] Edukacyjne konteksty współczesności - z myśla o przyszłości, red. J. Madalińska-Michalak, N.G. Pikuła, Kraków 2018, s. 333.

45 J. Kirenko, M. Duda, Bezrobocie - jakość życia..., s. 20. 
powoduje także wykluczenie tu i teraz na bardzo elementarnym poziomie. Wprowadzane obostrzenia pozbawiają pracy i dochodu $\mathrm{z}$ tego tytułu, co uniemożliwia zaspokajanie potrzeb własnych i rodzin. Obok tych trudności obecne są problemy natury psychologicznej, wynikające m.in. z izolacji społecznej, niepewności czy codziennych trudności egzystencjalnych, z którymi mierzy się i będzie się mierzyć większość społeczeństwa.

\section{Zakończenie}

Dokonane w artykule rozważania pozwalają ocenić wpływ pandemii COVID-19 na pomorski rynek pracy jako negatywny. Dobra sytuacja na pomorskim rynku pracy, odznaczająca się m.in. rekordowo niską stopą bezrobocia (od czerwca do grudnia 2019 r. - 4,4\%), trwała do początku 2020 r. Zmiany nadeszły pod koniec I kwartału 2020 r. wraz z pojawieniem się pandemii COVID-19 oraz wprowadzaniem obostrzeń i lockdownu. Zaprezentowane dane potwierdzają, że problemy na rynku pracy, przejawiające się m.in. wzrostem bezrobocia i zmniejszeniem liczby wolnych miejsc pracy, powróciły niczym Derridiańskie widmo ${ }^{46}$.

Obecnie dostrzegalne skutki pandemii nie są drastyczne, choć i tak ujawniają wiele negatywnych zjawisk. $Z$ prawdziwymi skutkami sytuacji epidemiologicznej w kraju i na świecie będziemy mierzyć się jeszcze długo, także po jej opanowaniu. Zjawisko to opisuje efekt histerezy - dotyczy on występowania negatywnych skutków zjawisk mimo ustania ich przyczyny. Dotychczasowe konsekwencje pandemii mają raczej umiarkowany poziom - po okresach zaostrzania przepisów czy wprowadzenia lockdownu następował powrót do względnej normalności, pozwalającej w jakimś stopniu „odrobić” straty. W dłuższej perspektywie nie da się jednak uniknąć negatywnych konsekwencji zamknięcia gospodarki, a te będą dawały o sobie znać po pewnym czasie, np. kiedy właściciele małych przedsiębiorstw mimo podejmowania licznych prób przetrwania kryzysu nie będą w stanie dalej prowadzić swoich biznesów.

Grupy, których sytuację na rynku pracy omówiłem nieco szerzej, należą do tzw. szczególnych kategorii osób na rynku pracy. Przedstawione dane statystyczne oraz dokonane analizy pokazują, że pandemia negatywnie oddziałuje na ich sytuację zawodową. Zarówno w przypadku kobiet, jak i osób młodych skutki będą widoczne, ponieważ pandemia pogłębia dotychczas występujące w tych grupach problemy.

Powrót widma bezrobocia, a dokładnie jego ponowny wzrost, pokazał, jak wiele jest do zrobienia na rynku pracy. Jak pisze Maksymilian Chutorański: „widma pojawiają się, by upomnieć się o ważne sprawy, o coś, co powinno zostać dokończone, załatwione, coś, co nie może zostać zapomniane, chociaż starano się o tym nie pamiętać" ${ }^{47}$. W okre-

${ }^{46}$ J. Derrida, Widma Marksa. Stan długu, praca żałoby i nowa Międzynarodówka, Warszawa 2016, s. 32.

${ }_{47}$ M. Chutorański, Materialność widma. Esej z pedagogiki nieantropocentrycznej [w:] Eduwidma..., s. 35 . 
sach poprawy koniunktury gospodarczej i ograniczenia negatywnych zjawisk na rynku pracy problemy na nim występujące schodzą na dalszy plan ${ }^{48}$. Pandemia wyraźnie odkryła i oświetliła występujące problemy, których rozwiązanie jest kluczowe nie tylko tu i teraz, lecz także w przyszłości, by zapobiec kolejnym załamaniom gospodarczym.

Kwestią podstawową dla szybkiego i skutecznego reagowania na potrzeby lokalnego rynku pracy jest jego ciągła i uważna obserwacja. Tylko ona dostarcza rzetelnych informacji o jego stanie, co stanowi punkt wyjścia do planowania działań. Relatywnie dobra na tle kraju sytuacja pomorskiego rynku pracy w 2019 r. spowodowała, że konsekwencje pandemii nie są tak dotkliwe, jak w innych regionach Polski, i nie tak głębokie, jak mogłyby być. Obecnie występujące zjawiska są negatywne, jednak ich ogólna skala (inną kwestią jest zróżnicowanie lokalne, które powoduje, że skutki są bardziej lub mniej dotkliwe) nie powinna budzić nadmiernych obaw, jednak, jak już wskazałem, rynek pracy wymaga ciągłej obserwacji.

\section{Bibliografia}

Aktywność ekonomiczna ludności w województwie pomorskim w III kwartale 2020 r., Główny Urząd Statystyczny w Gdańsku, 2020, www.gdansk.stat.gov.pl/opracowania-biezace/ opracowania-sygnalne/praca-wynagrodzenie/aktywnosc-ekonomiczna-ludnosci-w-wojewodztwie-pomorskim-w-iii-kwartale-2020-r-,3,43.html [dostęp: 7.12.2020].

Antkowiak Lech, Publiczne służby zatrudnienia w okresie pandemii COVID-19, www.porp. pl/uploads/original/122020/30/d3385e931b_LECH-ANTKOWIAK-ARTYKUL-NR-2.pdf [dostęp: 31.12.2020].

Baraniak Barbara, Edukacja przygotowujaca do pracy zawodowej szansa człowieka na wychodzenie z marginalizacji społecznej [w:] Edukacyjne konteksty współczesności - z myśla o przyszłości, red. Joanna Madalińska-Michalak, Norbert Gerard Pikuła, Impuls, Kraków 2018, s. 331-347.

Be a Lady They Said - Girls. Girls. Girls. Magazine, www.youtube.com/watch?v=z8ZSDS7zVdU\&feature=emb_title [dostęp: 24.02.2020].

Chutorański Maksymilian, Materialność widma. Esej z pedagogiki nieantropocentrycznej [w:] Eduwidma. Miejsca i rzeczy nawiedzone, red. Maria Mendel, Wydawnictwo Uniwersytetu Gdańskiego, Gdańsk 2020, s. 32-47.

Dane Banku Danych Lokalnych, www.bdl.stat.gov.pl/BDL/start[dostęp: 21.12.2020].

Derrida Jacques, Widma Marksa. Stan dlugu, praca żałoby i nowa Międzynarodówka, przekł. Tomasz Załuski, Wydawnictwo Naukowe PWN, Warszawa 2016.

Falkowska Katarzyna, Nowa rola urzędów pracy w czasie pandemii - seminarium dobrych praktyk 2020, https://porp.pl/pl/nowa-rola-urzedow-pracy-w-czasie-pandemii [dostęp: 29.10.2020].

48 I. Reszke, Wobec bezrobocia: opinie, stereotypy (Biblioteka Pracownika Socjalnego), Katowice 1999, s. 11. 
Flaszyńska Ewa, Bezrobocie, bezrobotny, praca socjalna, Seria Biblioteka Pracy Socjalnej, Difin, Warszawa 2019.

Informacja miesięczna o rynku pracy październik 2020 r., Wydział Pomorskiego Obserwatorium Rynku Pracy, Wojewódzki Urząd Pracy w Gdańsku, www.porp.pl/uploads/original/122020/09/fd035d6e18_Informacja-miesieczna-pazdziernik-2020.pdf [dostęp: 9.12.2020].

Informacja miesięczna o rynku pracy - listopad $2020 \mathrm{r}$., Wydział Pomorskiego Obserwatorium Rynku Pracy, Wojewódzki Urząd Pracy w Gdańsku, www.porp.pl/uploads/original/012021/08/aabe478bc8_Informacja-miesieczna-listopad-2020.pdf [dostęp: 8.01.2021].

Kaczmarczyk Kamila, Bierność i bezrobocie młodzieży w Polsce, Wydawnictwo Naukowe Uniwersytetu Mikołaja Kopernika, Toruń 2016.

Kirenko Janusz, Duda Marlena, Bezrobocie - jakosśc życia - uwarunkowania, Wydawnictwo Uniwersytetu Marii Curie-Skłodowskiej, Lublin 2018.

Maciejewska Dagmara, Zabłocka Barbara, Miniony rok zakończyliśmy rekordowo niskq stopa bezrobocia 4,4\%, www.porp.pl/pl/pomorskie-z-rekordowo-niska-stopa-bezrobocia-w-2019 [dostęp: 21.12.2020].

Ocena sytuacji na rynku pracy województwa pomorskiego i realizacji przez Samorzad Województwa Pomorskiego zadań w zakresie polityki rynku pracy za rok 2020, oprac. Wydział Pomorskiego Obserwatorium Rynku Pracy, WUP Gdańsk, www.porp.pl/uploads/ original/122020/01/2eb8a05818_Ocena-sytuacji-na-pomorskim-rynku-pracy.pdf [dostęp 1.12.2020].

Palka Katarzyna, Edukacja na wsi - mechanizmy wykluczenia edukacyjnego [w:] Pedagogika społeczna wobec zagrożeń człowieka i idei sprawiedliwości społecznej, V Zjazd Pedagogów Społecznych, t. 2, red. Wioleta Danilewicz, Wiesław Theiss, Wydawnictwo Akademickie Żak, Warszawa 2014, s. 361-370.

Radziewicz-Winnicki Andrzej, Pedagogika społeczna w obliczu realiów codzienności, Wydawnictwa Akademickie i Profesjonalne, Warszawa 2008.

Reszke Irena, Wobec bezrobocia: opinie, stereotypy, Biblioteka Pracownika Socjalnego, Wydawnictwo Śląsk, Katowice 1999.

Rutkowski Mateusz, Krypty pracy/nie-pracy, widmowanie bezrobocia i inne uobecnienia społecznej zbędności. Perspektywa społeczno-edukacyjna[w:] Eduwidma. Miejsca i rzeczy nawiedzone, red. Maria Mendel, Wydawnictwo Uniwersytetu Gdańskiego, Gdańsk 2020, s. 262-284.

Rutkowski Mateusz, Pomorski rynek pracy w listopadzie - kolejne restrykcje i ich negatywne skutki, www.porp.pl/pl/pomorski-rynek-pracy-w-listopadzie-kolejne-restrykcje-i-ich-negatywne-skutki [dostęp: 9.12.2020].

Rutkowski Mateusz, Pomorski rynek pracy w październiku - sytuacja się pogarsza i wzrasta niepewność przedsiębiorców, www.porp.pl/pl/pomorski-rynek-pracy-w-pazdzierniku-sytuacja-sie-pogarsza-i-wzrasta-niepewnosc-przedsiebiorcow [dostęp: 6.11.2020].

Sałata Elżbieta, Rola pracy zawodowej w życiu kobiet [w:] Marginalizacja na rynku pracy. Teorie a implikacje praktyczne, red. nauk. Norbert Gerard Pikuła, Oficyna Wydawnicza „Impuls”, Kraków 2015, s. 131-140. 
Spytek-Bandurska Grażyna, Aktywizacja zawodowa szczególnych kategorii bezrobotnych, Oficyna Wydawnicza ASPRA-JR, Warszawa 2010.

Szacunkowe dane o rynku pracy w województwie pomorskim - listopad 2020 r. Wydział Pomorskiego Obserwatorium Rynku Pracy, Wojewódzki Urząd Pracy w Gdańsku, www.porp.pl/uploads/original/122020/09/cf75b6618b_szacunkowe-dane-listopad-2020-r.pdf [dostęp: 9.12.2020].

Ślebarska Katarzyna, Wsparcie społeczne a zaradność człowieka w sytuacji bezrobocia. Studium konfrontatywne, Profesjonalny Pracownik Socjalny, Wydawnictwo Śląsk, Katowice 2010.

Środa Magdalena, Obcy, inny, wykluczony, Słowo/obraz terytoria, Gdańsk 2020.

Ulman Paweł, Sytuacja kobiet i mężczyzn na rynku pracy w Polsce [w:] Marginalizacja na rynku pracy. Teorie a implikacje praktyczne, red. Norbert Gerard Pikuła, Oficyna Wydawnicza „Impuls”, Kraków 2015, s. 117-130.

Właszczuk Julia, Manifest feministyczny, który stat się wiralem, www.vogue.pl/a/manifest-feministyczny-ktory-stal-sie-wiralem [dostęp: 26.02.2020].

Zych Adam Alfred, Aktywność zawodowa osób starszych na rynku pracy w cieniu pandemii koronawirusa, „Praca Socjalna” 2020, nr 6 (35), s. 21-33.

\section{Streszczenie}

W artykule podjęto próbę oceny wpływu pandemii COVID-19 na pomorski rynek pracy. Autor analizuje zmiany poszczególnych wskaźników opisujących sytuację na pomorskim rynku pracy oraz omawia trudności, z jakimi w sferze zawodowej w wyniku pandemii borykają się przedstawiciele szczególnych grup na rynku pracy - kobiety i osoby młode. Wnioski wskazują na negatywny wpływ pandemii COVID-19 na regionalny rynek pracy i zatrudnienie, a z negatywnymi konsekwencjami przyjdzie mierzyć się jeszcze długo po ustaniu pandemii.

Słowa kluczowe: rynek pracy, bezrobocie, młodzi na rynku pracy, sytuacja zawodowa kobiet, COVID-19

The impact of the COVID-19 pandemic on the Pomeranian employment market

Summary

The article is an attempt to assess the impact of the COVID-19 pandemic on the Pomeranian employment market. The author analyzes changes in individual indicators describing the situation on the Pomeranian labour market and discusses the difficulties faced in the professional sphere by representatives of specific groups on the labour market - women and young people as a result of the pandemic. The conclusions indicate the negative impact of the COVID-19 pandemic on the regional labour market and employment, and the negative consequences will be faced long after the pandemic ends.

Keywords: labour market, unemployment, young people on the labour market, professional situation of women, COVID-19 